Article

\title{
Tooth Wear Is Frequent in Adult Patients with Celiac Disease
}

\author{
Massimo Amato ${ }^{\dagger}$, Fabiana Zingone ${ }^{\dagger}$, Mario Caggiano ${ }^{(1)}$, Paola Iovino, Cristina Bucci \\ and Carolina Ciacci * \\ Department of Medicine, Surgery and Dentistry, Medical School of Salerno, 84131 Salerno, Italy; \\ mamato@unisa.it (M.A.); fabiana.zingone@outlook.com (F.Z.); macaggiano@unisa.it (M.C.); \\ piovino@unisa.it (P.I.); cristinabucci@hotmail.it (C.B.) \\ * Correspondence: cciacci@unisa.it; Tel.: +39-335-7816758 \\ + These authors contributed equally to this paper.
}

Received: 26 September 2017; Accepted: 30 November 2017; Published: 4 December 2017

\begin{abstract}
Background: Celiac disease (CD) patients can be affected by mouth and tooth disorders, which are influenced by their gluten-free diet. The aim of our research was to evaluate the pathological conditions of the stomatognathic system observed in celiac patients on a gluten-free diet. (2) Methods: we consecutively recruited celiac patients on a gluten-free diet at our celiac center, as well as healthy volunteers. Two dentists examined all patients/controls and checked them for any mouth disorder. (3) Results: Forty-nine patients affected by celiac disease (age at test $31.8 \pm 11.58$, time on GFD $8.73 \pm 7.7$ ) and 51 healthy volunteers (age at test $30.5 \pm 8.7$ ) were included. Recurrent aphthous stomatitis was reported in 26 patients $(53.0 \%)$ and in $13(25.5 \%)$ controls $(p=0.005)$. Dental enamel disorders were reported in 7 patients $(14.3 \%)$ and in 0 controls $(p=0.002)$, with none having geographic tongue. We found non-specific tooth wear, characterized by loss of the mineralized tissue of the teeth, in 9 patients $(18.3 \%)$ and in $3(5.9 \%)$ controls $(p=0.05)$. (4) Conclusion: Recurrent aphthous stomatitis and enamel hypoplasia are "risk indicators" that may suggest that an individual has $\mathrm{CD}$. We detected a high prevalence of non-specific tooth wear that can be caused by several factors such as malocclusion, sleep bruxism, parafunctional activity, and age.
\end{abstract}

Keywords: enamel hypoplasia; tooth wear; aphthosis; celiac disease

\section{Introduction}

Celiac disease (CD) is an immune-mediated systemic disorder caused by gluten, a protein found in wheat and some related cereals. In genetically susceptible individuals, gluten induces CD-specific antibodies (anti-transglutaminase and anti-endomysial antibodies) and enteropathy [1,2].

The prevalence of CD is about 1\% in Europe and the USA, and evidence shows that it is increasing worldwide [3-5]. The clinical presentation of CD ranges from a severe malabsorption syndrome to a number of extraintestinal symptoms [2]. Additionally, screening programs among first-degree relatives of patients with $\mathrm{CD}$, or patients with other autoimmune disorders, aid $\mathrm{CD}$ diagnosis in subjects with subclinical presentation or no symptoms [6]. It is now widely recognized that mouth and tooth disorders can affect CD $[7,8]$.

Enamel hypoplasia and recurrent aphthous stomatitis (RAS) have been the subject of many studies, with a particular focus on children. It is well-known that gluten exclusion does not influence the enamel hypoplasia, since the damage has already been established and it is irreversible $[7,8]$, whereas RAS improves on a gluten-free diet (GFD) [9]. Atrophic glossitis (also known as geographical tongue) is instead reported in CD before diagnosis [10].

The aim of our study was to evaluate the pathological conditions of the stomatognathic system (teeth and oral mucosa) observed in CD patients on a GFD. 


\section{Materials and Methods}

Over a period ranging from September 2015 to April 2016, we consecutively recruited a population composed of CD patients on a GFD, enrolled at the Gastroenterology Department of the University of Salerno, as well as healthy volunteers recruited among the hospital staff and the CD patients' friends. Two dentists (MA and MC) examined all the patients together. They did not attend the gastroenterological visit, and therefore they did not know to which group the subjects belonged (patient or control).

All procedures performed in studies involving human participants were in accordance with the ethical standards of the institutional and/or national research committee and with the 1964 Helsinki declaration and its later amendments or comparable ethical standards. This study protocol was approved by Regione Campania, San Giovanni di Dio e Ruggi D'Aragona, Salerno Ethic Committee in date 29 October 2012 with approval code 836.

Written informed consent was obtained from all individual participants included in the study.

The inclusion criteria for the celiac group were: age older than 18 years; positive CD-specific serology (anti-transglutaminase IgA and antiendomysial IgA in absence of IgA deficiency) and positive intestinal biopsy, or a B-C grade histology according to Corazza-Villanacci classification [11] before starting the GFD. All CD patients had to have been on a GFD for at least one year and have been anti-transglutaminase IgA negative at the time of the examination. We excluded patients who had received the CD diagnosis before the age of 3 (when deciduous teeth should be completed).

Inclusion criteria for the control group were: age older than 18 years; negativity to anti-transglutaminase antibodies; no gastroenterological disease; no infectious, immune-mediated, or auto-immune disorder.

Demographics and clinical information were collected during the gastroenterological visit, and data were recorded in a dedicated database. At the moment of the dental visit, patients were asked about recurrent aphthous stomatitis (RAS) characterized by recurrent bouts of solitary or multiple shallow painful ulcers, at intervals of a few months to a few days in patients who were otherwise well (Figure 1) [12]. Aphthosis at the time of the exam was also detected.

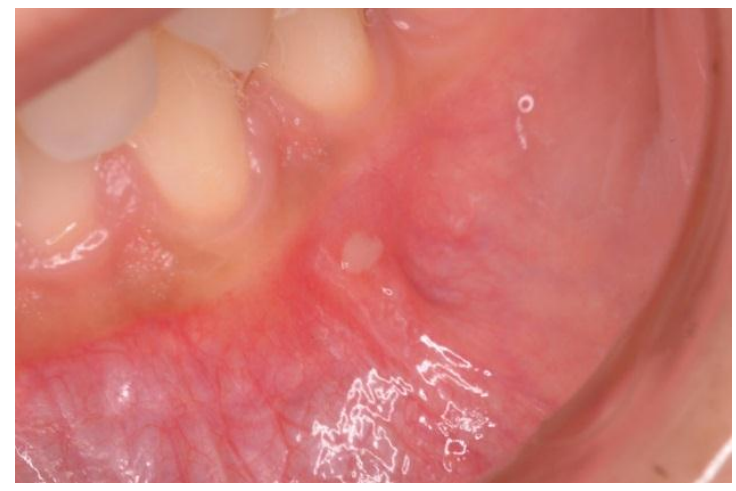

Figure 1. A case of aphthosis on the buccal mucosa.

The color, type, and site of dental enamel defects were recorded and classified according to Aine classification [8,13]. According to Aine, enamel defects appear symmetrically and chronologically in the same anatomical groups of teeth in all four quadrants of dentition, while single and asymmetrical changes were regarded as highly unspecific to CD. Enamel hypoplasia, in particular, is characterized by a reduced deposition of the enamel matrix by the ameloblasts. This alteration is clinically featured by depressions or grooves on the surface of the tooth (Figure 2). 


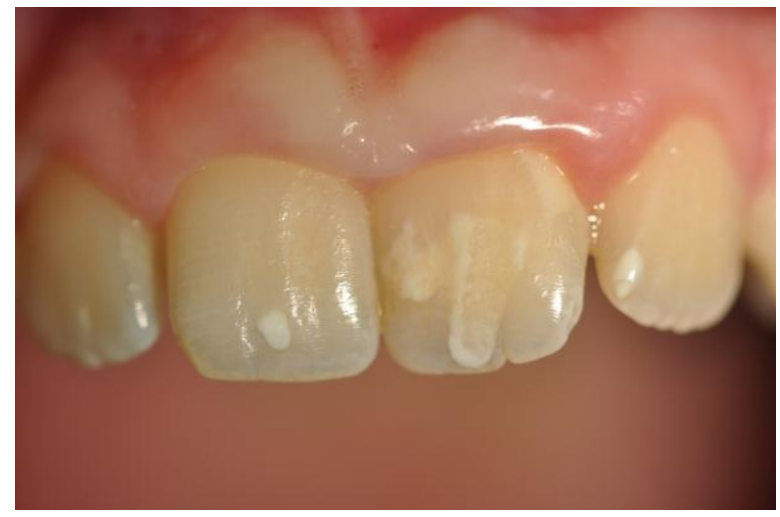

Figure 2. A case of enamel hypoplasia in a celiac disease (CD) patient.

Depending on the severity, it can vary from a mere change of color towards chalky white or gray and brownish, to areas of leakage of substances, up to severe cases of complete absence of enamel. Finally, the presence of atrophic glossitis (geographic tongue) was detected, which is characterized by glossodynia, atrophy of the filiform papillae, and erythematous areas on the back of the tongue.

\section{Statistical Analysis}

Categorical and continuous variables were expressed as frequency and mean \pm standard deviation (SD), respectively. Differences in frequencies between the groups were calculated using the $\chi^{2}$ test, while differences between continuous variables were calculated using the $t$-test. We compared the two groups according to age, sex, smoking habit, and alcohol consumption. All tests were two-tailed with significance level set at $p<0.05$. All of the analyses were performed using Stata version 12, Stata Corp., College Station, TX, USA.

\section{Results}

Sixty-five CD patients consecutively attending the celiac center at the University of Salerno during the study period were eligible to participate in the study. However, thirteen patients refused to undergo the oral examination, and three had received the $\mathrm{CD}$ diagnosis before the age of three. Forty-nine people agreed to participate and were enrolled -37 females $(75.5 \%)$ whose age at test was $31.8 \pm 11.58$ years, and whose time on GFD was $8.73 \pm 7.7$ years. Fifty-one controls were included in the study- 31 females $(60.8 \%)$, whose age at test was $30.5 \pm 8.7$ years. There were no statistically significant differences between the two groups in terms of sex, age, smoking habit, or alcohol consumption $(p>0.05)$. RAS was reported in $26 \mathrm{CD}$ patients $(53.0 \%)$ and in $13(25.5 \%)$ controls $(p=0.005)$ (see Table 1$)$.

Twenty-four CD patients reported recurrence of aphthosis before the CD diagnosis, while only two patients had had two aphthosis episodes within one year of diagnosis. No patient or control had aphthosis at the time of the dental examination. Dental enamel disorders were reported in seven celiac patients $(14.3 \%)$ and in 0 controls $(p=0.002)$. In particular, four patients had a grade 1 , according to Aine classification (defects in color of enamel, single or multiple cream, yellow, or brown opacities with clearly defined or diffuse margins), and three had a grade 2 according to Aine (slight structural defects, rough enamel surface filled with horizontal grooves or shallow pits) (see Table 1). As enamel hypoplasia is a sign of early gluten damage (before teething), we compared the age at diagnosis between those with and without enamel hypoplasia, but we did not observe any significant statistical difference between them ( $25.6 \pm 10.6$ vs. $22.48 \pm 13.4, p=0.5)$. None had atrophic glossitis at the time of the oral examination. During the dental examination, we accidentally found that nine CD patients $(18.3 \%)$ and three $(5.9 \%)$ controls $(p=0.05)$ showed non-specific tooth wear (see Table 1$)$, characterized by loss of mineralized tooth tissue, unrelated to bacterial demineralization action. We adopted the Smith and Knight tooth wear index to classify these lesions [14]. 
Table 1. Lesions found during the dental examination in cases and controls.

\begin{tabular}{|c|c|c|c|}
\hline & $\begin{array}{c}\text { CD Patients (49) } \\
n(\%)\end{array}$ & $\begin{array}{c}\text { Controls (51) } \\
n(\%)\end{array}$ & $p$ \\
\hline RAS & $26(53)$ & $13(25.5)$ & 0.005 \\
\hline Aphthosis during visit & 0 & 0 & \\
\hline Enamel hypoplasia & $7(14.3)$ & \multirow{5}{*}{0} & \multirow{5}{*}{0.002} \\
\hline Aine grade 1 & 4 & & \\
\hline Aine grade 2 & 3 & & \\
\hline Aine grade 3 & 0 & & \\
\hline Aine grade 4 & 0 & & \\
\hline Atrophic glossitis & 0 & 0 & \\
\hline Non-specific enamel wear & $9(18.3)$ & $3(5.9)$ & \multirow{5}{*}{0.05} \\
\hline Smith and Knight index grade 1 & 4 & 3 & \\
\hline Smith and Knight index grade 2 & 3 & 0 & \\
\hline Smith and Knight index grade 3 & 2 & 0 & \\
\hline Smith and Knight index grade 4 & 0 & 0 & \\
\hline
\end{tabular}

$\mathrm{CD}$, celiac disease; RAS, recurrent aphthous stomatitis.

Following this classification we observed: Score 1 (loss of enamel characteristics) in four CD patients, Score 2 (exposing dentine for less than one-third of surface) in three, Score 3 (exposing dentine for more than one-third of surface) in two (Figure 3). In the control group, we only found three patients with tooth wear, all classified as Score 1.

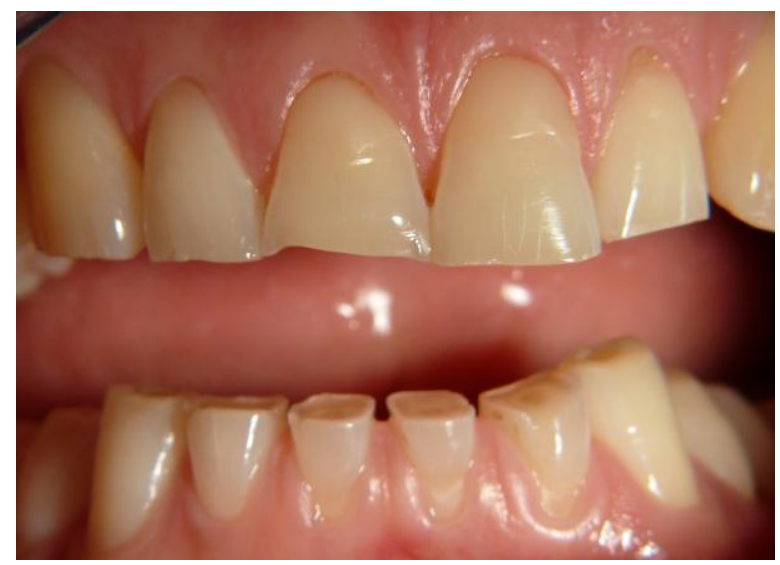

Figure 3. A case of tooth wear in a celiac disease (CD) patient (Score 3).

\section{Discussion}

This case-control analysis confirmed the higher prevalence of enamel hypoplasia and RAS in $\mathrm{CD}$ patients compared to the general population, and evidenced the presence of a new possible sign of CD diagnosis based on the presence of non-specific tooth wear that was accidentally found during the dental visit. The strength of this study is that the two dentists-blinded to the subjects' status-conducted the oral examination employing standardized methods. We exclusively included adult patients on a GFD to detect which disorders are unrelated to the elimination of gluten. However, the study can be considered limited due to the small size of the sample, which may have influenced our results, and because we did not have data on the dental disorders at the time of diagnosis. 
Oral disorders have been associated with CD and other immune-mediated diseases, such as Crohn's disease $[15,16]$. Moreover, stress, anxiety, and sleep disturbances can also function as additional triggers [17]. In studies conducted on children and/or adults, CD and both enamel hypoplasia and RAS have been clearly associated. Tables 2 and 3 summarize these studies published since the year 2000. Compared to these studies, we found a higher prevalence of RAS (53\%) but a lower prevalence of enamel hypoplasia (14.3\%).

In 1968, Lehner [18] first suggested that the aphthous lesions in undiagnosed CD patients could be the consequence of immunological mechanisms. In 1992, Majorana found the presence of aphthae in $19(16.8 \%)$ out of $113 \mathrm{CD}$ patients at diagnosis, and reported that the frequency of these lesions decreased while on a GFD [19]. Moreover, the study showed that the re-exposition to gluten determined the recurrence of the sores, as well as an increase in the level of antibodies and intestinal damage.

Table 2. Previous literature on the association between celiac disease (CD) and recurrent aphthous stomatitis (RAS).

\begin{tabular}{|c|c|c|c|c|}
\hline Author & Country & Number of Subjects & Population studied & $\begin{array}{c}\text { Prevalence of RAS } \\
\text { Detected }\end{array}$ \\
\hline Bucci 2006 [24] & Italy & $\begin{array}{l}\text { CD Patients: } 72 \\
\text { Controls: } 162\end{array}$ & Children & $\begin{array}{l}\text { CD Patients: } 33.3 \% \\
\text { Controls: } 23.4 \%\end{array}$ \\
\hline Campisi 2007 [9] & Italy & $\begin{array}{l}\text { CD Patients: }(90 / 107) \\
\text { Controls: }(180 / 233)\end{array}$ & Adults and Children & $\begin{array}{l}\text { Adult CD Patients: } 21 \% \\
\text { Adult Controls: } 0.5 \% \\
\text { Pediatric CD Patients: } 17 \% \\
\text { Pediatric Controls: } 1 \%\end{array}$ \\
\hline Procaccini 2007 [20] & Italy & $\begin{array}{l}\text { CD Patients: } 50 \\
\text { Controls: } 50\end{array}$ & Children/young adult & $\begin{array}{l}\text { CD Patients: } 36 \% \\
\text { Controls: } 12 \%\end{array}$ \\
\hline Cheng 2010 [21] & USA & $\begin{array}{l}\text { CD Patients: } 67 \\
\text { Controls: } 69\end{array}$ & Adults and Children & $\begin{array}{c}\text { CD Patients: } 42.4 \% \\
\text { Controls: } 23.2 \%\end{array}$ \\
\hline Costacurta 2010 [25] & Italy & $\begin{array}{l}\text { CD Patients: } 300 \\
\text { Controls: } 300\end{array}$ & Children & $\begin{array}{l}\text { CD Patients: } 8.3 \% \\
\text { Controls: } 3 \%\end{array}$ \\
\hline Erriu 2013 [26] & Italy & CD Patients: 44 & Children & CD Patients: $18.2 \%$ \\
\hline de Carvalho 2015 [22] & Brazil & $\begin{array}{l}\text { CD Patients: } 52 \\
\text { Controls: } 52\end{array}$ & Children & $\begin{array}{l}\text { CD Patients: } 40.3 \% \\
\text { Controls: } 17.3 \%\end{array}$ \\
\hline Cantekin 2015 [23] & Turkey & $\begin{array}{l}\text { CD Patients: } 25 \\
\text { Controls: } 25\end{array}$ & Children & $\begin{array}{l}\text { CD Patients: } 44 \% \\
\text { Controls: } 0 \%\end{array}$ \\
\hline This Study 2017 & Italy & $\begin{array}{l}\text { CD Patients: } 49 \\
\text { Controls: } 51\end{array}$ & Adults & $\begin{array}{l}\text { CD Patients: } 53 \% \\
\text { Controls: } 25.5 \%\end{array}$ \\
\hline
\end{tabular}

GFD: gluten-free diet.

As shown in Table 2, an Italian case-control study carried out in 2007 showed that in children with CD, RAS had a higher frequency and a higher rate of recurrence compared to the control group [20]. Another Italian study further confirmed this finding, reporting that RAS was present in 21\% (19/90) of CD adult patients and $0.5 \%(1 / 180)$ of controls [9]. A high frequency of RAS in CD was also reported by studies conducted in the USA (42.4\% in CD vs. $23.2 \%$ in controls) [21], Brazil (40.3\% in celiac and $17.3 \%$ in control) [22], and Turkey (44\% in celiac and $0 \%$ in control) [23].

Contrary to these data, a previous study failed to demonstrate the association between CD and RAS (33.3\% of celiac patients and $23.4 \%$ of controls, $p>0.05)$ [24].

Enamel hypoplasia in the permanent dentition is usually bilateral, symmetrical, more frequently found on the central incisors, upper lateral, and lower ones, the cusps of the first molars and canines, and pre-molars. To-date, the pathogenesis of enamel defects in CD has not had a clear explanation. The more accredited hypothesis is that the damage is the effect of poor mineralization caused by the malabsorption of calcium, phosphate, and vitamin D [24,27,28]. The low concentration of calcium caused by intestinal malabsorption and observed in patients during tooth development is indeed involved in the development of enamel hypoplasia [28,29]. 
However, different immune or genetic genesis of lesions cannot be excluded. T-lymphocytes may have a role in attacking the enamel [30,31], and there may be an association between dental enamel effects and the haplotype HLA-DR3 even in the general population. On the contrary, the DR5-DR7 phenotype has been associated with protection from damage to the enamel, explaining why not all CD patients suffer from enamel hypoplasia [19,30].

Other systemic factors (e.g., malnutrition and reduced concentration of vitamin D and A) are possibly involved in enamel hypoplasia in $\mathrm{CD}$ and other diseases causing malnutrition. The prevalence of dental enamel hypoplasia/defects varies among the studies.

Aguirre et al. noted that enamel defects were observed in $72(52.5 \%)$ patients with CD and 22 $(42.3 \%)$ control subjects $(p=0.006)$; they mostly affected the incisors $(70.8 \%)$ and canines $(20.8 \%)$ at the level of a permanent incisal third of the crown [32]. Italian studies based on children and/or adults found a prevalence of enamel hypoplasia ranging between $20 \%$ and $85.2 \%$ in CD patients $[8,9,20,25,26]$. Other studies confirmed that defects in the development of the enamel are more frequently found in patients with CD rather than in healthy individuals [21,23,33,34] (see Table 3).

Table 3. Previous literature on the association between celiac disease (CD) and enamel hypoplasia.

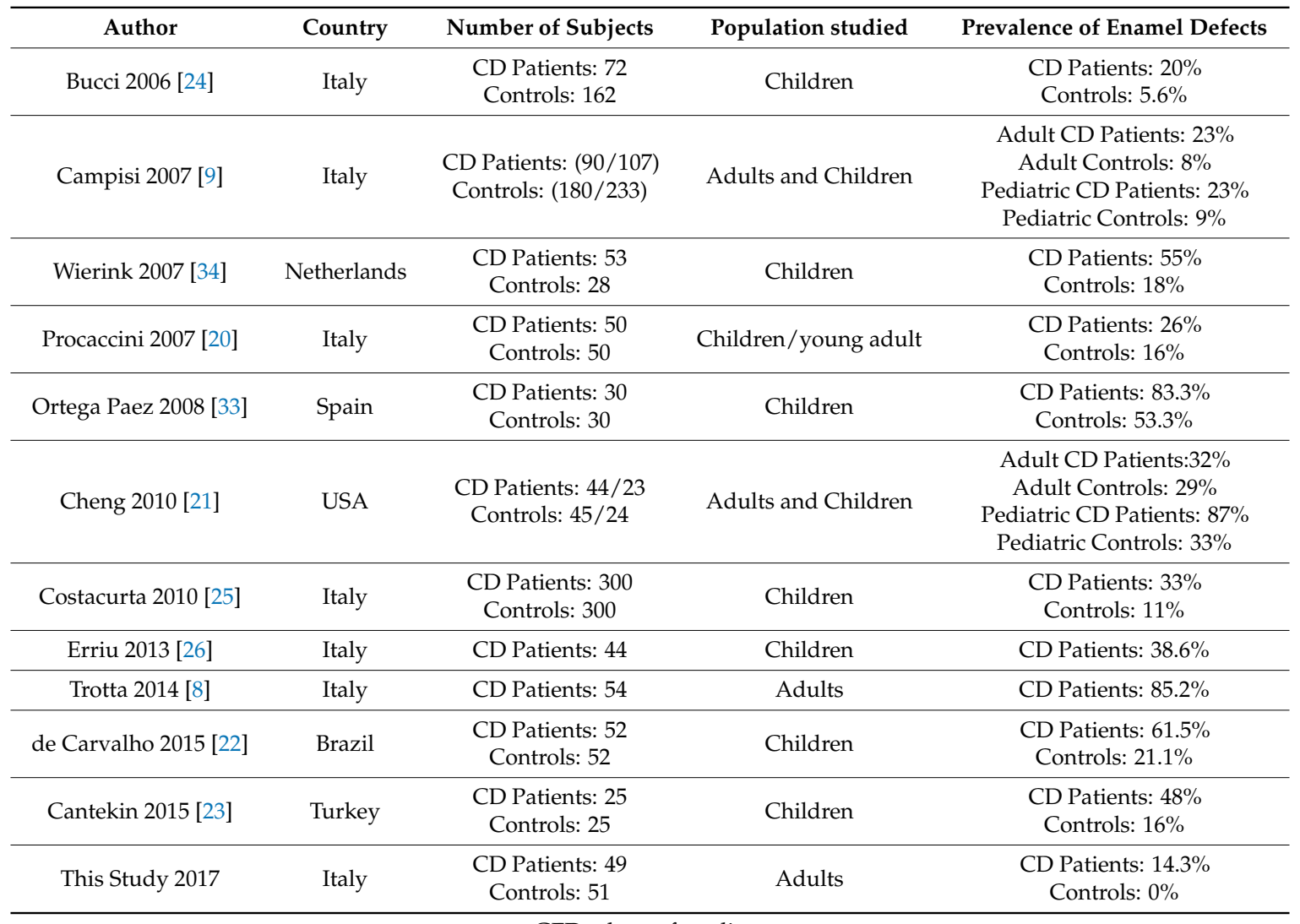

GFD: gluten-free diet.

It has been suggested that a higher prevalence of enamel lesions might be more common in patients with non-gastrointestinal complaints of $\mathrm{CD}$, compared to those expressing the typical malabsorption syndrome [35]. A structural difference between the enamel hypoplasia observed in CD patients and other individuals has been reported, showing that $C D$ patients have a reduced degree of mineralization of the enamel, shorter prisms, and a lower content of interprismatic substance, which is even more asymmetrically distributed than in non-CD subjects [35].

The new finding of our study is that we detected a high prevalence of non-specific tooth wear which can be caused by several factors, including malocclusion, sleep bruxism, parafunctional activity, and age [36]. The tooth wear has been associated with sleep disorders, eating disorders, 
and psychological problems [37-39]; similarly, $\mathrm{CD}$ is a condition that is associated with psychological impairment in both untreated and treated conditions [40-43]. Future prospective studies should therefore analyze this possible association in CD.

In conclusion, RAS and enamel hypoplasia have been found more in CD patients than in controls, and they can be considered as "risk indicators"; these may suggest that an individual has CD, and thus prompt a focused work-up. Moreover, future studies should analyze the significance of non-specific tooth wear in CD patients and their association with psychological disorders in patients with CD preand post-diagnosis.

Acknowledgments: We are grateful to Regione Campania (Le Patologie della nutrizione e del metabolismo nell'adulto in Campania: appropriatezza prescrittiva secondo il DM 8 giugno 2001, Assistenza sanitaria integrativa relativa ai prodotti destinati ad una alimentazione particolare. (G.U. Serie Generale n. 154 del 5 luglio 2001) for supporting Zingone and Bucci. This work was also partly supported by FC (Fondazione Celiachia Onlus) Grant FC 008_2015, PI Ciacci.

Author Contributions: Massimo Amato, Fabiana Zingone developed the study design and the data acquisition. Cristina Bucci, Mario Caggiano and Fabiana Zingone collected the data, designed the analysis, and analyzed the data. Massimo Amato, Fabiana Zingone, Mario Caggiano, Paola Iovino, Carolina Ciacci and Cristina Bucci wrote, reviewed and commented on the paper. Carolina Ciacci provided for ethical committee and gave the final approval of the version to be submitted.

Conflicts of Interest: The authors declare no conflict of interest.

\section{References}

1. Ludvigsson, J.F.; Bai, J.C.; Biagi, F.; Card, T.R.; Ciacci, C.; Ciclitira, P.J.; Green, P.H.; Hadjivassiliou, M.; Holdoway, A.; van Heel, D.A.; et al. Diagnosis and management of adult coeliac disease: Guidelines from the british society of gastroenterology. Gut 2014, 63, 1210-1228. [CrossRef] [PubMed]

2. Ludvigsson, J.F.; Leffler, D.A.; Bai, J.C.; Biagi, F.; Fasano, A.; Green, P.H.; Hadjivassiliou, M.; Kaukinen, K.; Kelly, C.P.; Leonard, J.N.; et al. The Oslo definitions for coeliac disease and related terms. Gut 2013, 62, 43-52. [CrossRef] [PubMed]

3. Zingone, F.; West, J.; Crooks, C.J.; Fleming, K.M.; Card, T.R.; Ciacci, C.; Tata, L.J. Socioeconomic variation in the incidence of childhood coeliac disease in the UK. Arch. Dis. Child. 2015, 100, 466-473. [CrossRef] [PubMed]

4. West, J.; Fleming, K.M.; Tata, L.J.; Card, T.R.; Crooks, C.J. Incidence and prevalence of celiac disease and dermatitis herpetiformis in the UK over two decades: Population-based study. Am. J. Gastroenterol. 2014, 109, 757-768. [CrossRef] [PubMed]

5. Kang, J.; Kang, A.; Green, A.; Gwee, K.; Ho, K. Systematic review: Worldwide variation in the frequency of coeliac disease and changes over time. Aliment. Pharmacol. Ther. 2013, 38, 226-245. [CrossRef] [PubMed]

6. Aggarwal, S.; Lebwohl, B.; Green, P.H. Screening for celiac disease in average-risk and high-risk populations. Ther. Adv. Gastroenterol. 2012, 5, 37-47. [CrossRef] [PubMed]

7. Krzywicka, B.; Herman, K.; Kowalczyk-Zajac, M.; Pytrus, T. Celiac disease and its impact on the oral health status-Review of the literature. Adv. Clin. Exp. Med. 2014, 23, 675-681. [CrossRef] [PubMed]

8. Trotta, L.; Biagi, F.; Bianchi, P.I.; Marchese, A.; Vattiato, C.; Balduzzi, D.; Collesano, V.; Corazza, G.R. Dental enamel defects in adult coeliac disease: Prevalence and correlation with symptoms and age at diagnosis. Eur. J. Intern. Med. 2013, 24, 832-834. [CrossRef] [PubMed]

9. Campisi, G.; Di Liberto, C.; Iacono, G.; Compilato, D.; Di Prima, L.; Calvino, F.; Di Marco, V.; Lo Muzio, L.; Sferrazza, C.; Scalici, C.; et al. Oral pathology in untreated coeliac [corrected] disease. Aliment. Pharmacol. Ther. 2007, 26, 1529-1536. [CrossRef] [PubMed]

10. Cigic, L.; Galic, T.; Kero, D.; Simunic, M.; Medvedec Mikic, I.; Kalibovic Govorko, D.; Biocina Lukenda, D. The prevalence of celiac disease in patients with geographic tongue. J. Oral Pathol. Med. 2016, 45, 791-796. [CrossRef] [PubMed]

11. Corazza, G.R.; Villanacci, V. Coeliac disease. J. Clin. Pathol. 2005, 58, 573-574. [CrossRef] [PubMed]

12. Jurge, S.; Kuffer, R.; Scully, C.; Porter, S.R. Mucosal Disease series. Number VI. Recurrent aphthous stomatitis. Oral Dis. 2006, 12, 1-21. [CrossRef] [PubMed] 
13. Aine, L. Permanent tooth dental enamel defects leading to the diagnosis of coeliac disease. Br. Dent. J. 1994, 177, 253-254. [CrossRef] [PubMed]

14. Smith, B.G.; Knight, J.K. An index for measuring the wear of teeth. Br. Dent. J. 1984, 156, 435-438. [CrossRef] [PubMed]

15. Ciacci, C.; Bucci, C.; Zingone, F.; Iovino, P.; Amato, M. Buccal localization of Crohn's disease with long-term infliximab therapy: A case report. J. Med. Case Rep. 2014, 8, 397. [CrossRef] [PubMed]

16. Mignogna, M.D.; Fortuna, G.; Leuci, S.; Amato, M. Oral Crohn's disease: A favorable clinical response with delayed-release triamcinolone acetonide intralesional injections. Am. J. Gastroenterol. 2008, 103, 2954-2955. [CrossRef] [PubMed]

17. Adamo, D.; Ruoppo, E.; Leuci, S.; Aria, M.; Amato, M.; Mignogna, M.D. Sleep disturbances, anxiety and depression in patients with oral lichen planus: A case-control study. J. Eur. Acad. Dermatol. Venereol. 2015, 29, 291-297. [CrossRef] [PubMed]

18. Lehner, T. Autoimmunity in oral diseases, with special reference to recurrent oral ulceration. Proc. R. Soc. Med. 1968, 61, 515-524. [PubMed]

19. Majorana, A.; Sapelli, P.L.; Malagoli, A.; Meini, A.; Pillan, M.N.; Duse, M.; Ugazio, A.G. Celiac disease and recurrent aphthous stomatitis. The clinical and immunogenetic aspects. Minerva Stomatol. 1992, 41, 33-40. [PubMed]

20. Procaccini, M.; Campisi, G.; Bufo, P.; Compilato, D.; Massaccesi, C.; Catassi, C.; Lo Muzio, L. Lack of association between celiac disease and dental enamel hypoplasia in a case-control study from an Italian central region. Head Face Med. 2007, 3, 25. [CrossRef] [PubMed]

21. Cheng, J.; Malahias, T.; Brar, P.; Minaya, M.T.; Green, P.H. The association between celiac disease, dental enamel defects, and aphthous ulcers in a United States cohort. J. Clin. Gastroenterol. 2010, 44, 191-194. [CrossRef] [PubMed]

22. De Carvalho, F.K.; de Queiroz, A.M.; Bezerra da Silva, R.A.; Sawamura, R.; Bachmann, L.; Bezerra da Silva, L.A.; Nelson-Filho, P. Oral aspects in celiac disease children: Clinical and dental enamel chemical evaluation. Oral Surg. Oral Med. Oral Pathol. Oral Radiol. 2015, 119, 636-643. [CrossRef] [PubMed]

23. Cantekin, K.; Arslan, D.; Delikan, E. Presence and distribution of dental enamel defects, recurrent aphthous lesions and dental caries in children with celiac disease. Pak. J. Med. Sci. 2015, 31, 606-609. [CrossRef] [PubMed]

24. Bucci, P.; Carile, F.; Sangianantoni, A.; D'Angio, F.; Santarelli, A.; Lo Muzio, L. Oral aphthous ulcers and dental enamel defects in children with coeliac disease. Acta. Paediatr. 2006, 95, 203-207. [CrossRef] [PubMed]

25. Costacurta, M.; Maturo, P.; Bartolino, M.; Docimo, R. Oral manifestations of coeliac disease: A clinical-statistic study. Oral Implantol. 2010, 3, 12-19.

26. Erriu, M.; Abbate, G.M.; Pili, F.M.; Novara, F.; Orru, G.; Montaldo, C.; Piras, V.; Levrini, L. Oral signs and HLA-DQB1 *02 haplotypes in the celiac paediatric patient: A preliminary study. Autoimmun. Dis. 2013, 2013, 389590. [CrossRef] [PubMed]

27. Pastore, L.; Campisi, G.; Compilato, D.; Lo Muzio, L. Orally based diagnosis of celiac disease: Current perspectives. J. Dent. Res. 2008, 87, 1100-1107. [CrossRef] [PubMed]

28. Mariani, P.; Mazzilli, M.C.; Margutti, G.; Lionetti, P.; Triglione, P.; Petronzelli, F.; Ferrante, E.; Bonamico, M. Coeliac disease, enamel defects and HLA typing. Acta Paediatr. 1994, 83, 1272-1275. [CrossRef] [PubMed]

29. Nikiforuk, G.; Fraser, D. The etiology of enamel hypoplasia: A unifying concept. J. Pediatr. 1981, 98, 888-893. [CrossRef]

30. Petrecca, S.; Giammaria, G.; Giammaria, A.F. Oral cavity changes in the child with celiac disease. Minerva Stomatol. 1994, 43, 137-140. [PubMed]

31. Sonora, C.; Arbildi, P.; Rodriguez-Camejo, C.; Beovide, V.; Marco, A.; Hernandez, A. Enamel organ proteins as targets for antibodies in celiac disease: Implications for oral health. Eur. J. Oral Sci. 2016, 124, 11-16. [CrossRef] [PubMed]

32. Aguirre, J.M.; Rodriguez, R.; Oribe, D.; Vitoria, J.C. Dental enamel defects in celiac patients. Oral Surg. Oral Med. Oral Pathol. Oral Radiol. Endod. 1997, 84, 646-650. [CrossRef]

33. Ortega Paez, E.; Junco Lafuente, P.; Baca Garcia, P.; Maldonado Lozano, J.; Llodra Calvo, J.C. Prevalence of dental enamel defects in celiac patients with deciduous dentition: A pilot study. Oral Surg. Oral Med. Oral Pathol. Oral Radiol. Endod. 2008, 106, 74-78. [CrossRef] [PubMed] 
34. Wierink, C.D.; van Diermen, D.E.; Aartman, I.H.; Heymans, H.S. Dental enamel defects in children with coeliac disease. Int. J. Paediatr. Dent. 2007, 17, 163-168. [CrossRef] [PubMed]

35. Bossu, M.; Bartoli, A.; Orsini, G.; Luppino, E.; Polimeni, A. Enamel hypoplasia in coeliac children: A potential clinical marker of early diagnosis. Eur. J. Paediatr. Dent. 2007, 8, 31-37. [PubMed]

36. Kaidonis, J.A. Tooth wear: The view of the anthropologist. Clin. Oral Investig. 2008, 12 (Suppl. 1), S21-S26. [CrossRef] [PubMed]

37. Ahlberg, J.; Lobbezoo, F.; Ahlberg, K.; Manfredini, D.; Hublin, C.; Sinisalo, J.; Kononen, M.; Savolainen, A. Self-reported bruxism mirrors anxiety and stress in adults. Med. Oral Patol. Oral Cir. Bucal 2013, 18, e7-e11. [CrossRef] [PubMed]

38. Serra-Negra, J.M.; Scarpelli, A.C.; Tirsa-Costa, D.; Guimaraes, F.H.; Pordeus, I.A.; Paiva, S.M. Sleep bruxism, awake bruxism and sleep quality among Brazilian dental students: A cross-sectional study. Braz. Dent. J. 2014, 25, 241-247. [CrossRef] [PubMed]

39. Bruno, V.; Amato, M.; Catapano, S.; Iovino, P. Dental erosion in patients seeking treatment for gastrointestinal complaints: A case series. J. Med. Case Rep. 2015, 9, 250. [CrossRef] [PubMed]

40. Zingone, F.; Siniscalchi, M.; Capone, P.; Tortora, R.; Andreozzi, P.; Capone, E.; Ciacci, C. The quality of sleep in patients with coeliac disease. Aliment. Pharmacol. Ther. 2010, 32, 1031-1036. [CrossRef] [PubMed]

41. Zingone, F.; Swift, G.L.; Card, T.R.; Sanders, D.S.; Ludvigsson, J.F.; Bai, J.C. Psychological morbidity of celiac disease: A review of the literature. United Eur. Gastroenterol. J. 2015, 3, 136-145. [CrossRef] [PubMed]

42. Passananti, V.; Siniscalchi, M.; Zingone, F.; Bucci, C.; Tortora, R.; Iovino, P.; Ciacci, C. Prevalence of eating disorders in adults with celiac disease. Gastroenterol. Res. Pract. 2013, 2013, 7. [CrossRef] [PubMed]

43. De Rosa, A.; Troncone, A.; Vacca, M.; Ciacci, C. Characteristics and quality of illness behavior in celiac disease. Psychosomatics 2004, 45, 336-342. [CrossRef] [PubMed]

(C) 2017 by the authors. Licensee MDPI, Basel, Switzerland. This article is an open access article distributed under the terms and conditions of the Creative Commons Attribution (CC BY) license (http://creativecommons.org/licenses/by/4.0/). 